\title{
CENTRAL BANK INDEPENDENCE AND INFLATION IN EU-28
}

\author{
Daniela-Georgeta BEJU \\ "Babeş-Bolyai" University of Cluj-Napoca, Romania \\ daniela.beju@econ.ubbcluj.ro \\ Maria-Lenuța CIUPAC-ULICI \\ IPAG Business School Paris, France \& \\ Commercial Academy Satu-Mare, Romania \\ ulici_maria@yahoo.com \\ Codruța-Maria FǍT \\ "Babeş-Bolyai" University of Cluj-Napoca, Romania \\ codruta.fat@econ.ubbcluj.ro
}

\begin{abstract}
Today, both policymakers and academicians consider that the central bank's main goal is to guarantee price stability. The central bank can sustain the government's economic policies, but only without prejudicing this objective. In order to focus on price stability several studies found that central bank should have a high level of independence. This is why during the recent decades the majority of developed countries, but also several emerging economies have employed institutional reforms that conferred their monetary authorities - the central bank - more independence.

Within the European Union the central bank independence is a crucial issue, since the Maastricht Treaty stipulates that one requirement for joining Economic and Monetary Union for the candidate member states is to give their central banks a sufficiently high level of independence. This official requirement has encouraged the countries from Centre and East Europe engaged on the way to adhere the Economic and Monetary Union to confer their central bank a great level of independence.

In this paper we analyze some important theoretic issues about central bank independence. We also make an empirical investigation regarding the evolution of inflation within European Union relative to the independence of member states' central banks.
\end{abstract}

KEYWORDS: central bank independence, inflation, monetary policy, EU-28

\section{Introduction}

Since the oldest central bank was establishes (Bank of Sweden - 1668), the central banking have suffered many changes. Besides their traditional tasks, the DOI: 10.1515/raft-2017-0034

(C) 2017. This work is licensed under the Creative Commons Attribution-NonCommercial-NoDerivatives 3.0 License. majority of central banks was set for and serves the government's interests for many years. The most important changes in central banks governance have taken place in the last three decades: due to the 
expanding of inflation in the '70, many countries adopted reforms through which they have conferred more independence to central bank.

In some cases the older institutions were basically reorganized (Bank of England, for example), but in other cases the new central banks were established (the 15 new central banks of the former Soviet Union countries, for example). Moreover, the most recent established central bank European Central Bank - was created at the time the single currency euro was adopted, in order to manage monetary union and it was given with a high degree of independence. All these institutional reforms implied the improvement of central bank law or adopted of a new one (in the case of new established central banks), at the same time as institutional objectives, practices and structures were revised or implemented (Crowe \& Meade, 2007, p. 69). In many cases the price stability was set as main goal of central bank's monetary policy.

\section{Central Bank Independence}

2.1. The Necessity of Central Bank

\section{Independence}

The central bank independence's issue is as old as the central banking, having been discussed from hundreds of years. Maybe, the first important remarks regarding the independence belong to David Ricardo (1824), who sees the independence of central bank, as the "autonomy from the government and nonfinancing of budgets" (Fraser, 1994, p. 1). The issue of central bank independence has gained an increasing importance once the inflation was spreading worldwide during the '70 and a new phenomenon was arisen - stagflation.

Furthermore, some studies, carrying out beginning with ' 70 , consider that central bank independence might be a solution of time inconsistency problem - a problem discussed in the theory developed by Kydland \& Prescott (1977) and Barro \& Gordon (1983). These economic theoreticians showed that time-inconsistency problem occurs since the policies judged to be the best at the present time for the future are no longer the best when the future period starts and, in consequence, they aren't put into practice (Richard, 2003, pp. 1-3). Instead, discretionary policies would be implemented, which, in fact, are inflationary policies, because a central bank that implements a discretionary monetary policy is pressured by politicians to force the economy to develop more rapidly than its limits and to decrease the unemployment. Thus, the result of this policy would be a higher inflation on the long term, because the economy is not able to go over its potential GDP and its natural rate of unemployment on long term (Kydland \& Prescott, 1977, Barro \& Gordon, 1983).

To avoid the problem of time inconsistency, two solutions might be putted in practice. On the one hand, Rogoff (1985, p. 1187) found as solution to this problem to delegate the monetary policy to an agent that is highly adverse to inflation and isolate it from the government, explaining why a lot of countries have established "an independent central bank and choose its governors from conservative elements of the financial economy". On the other hand, Walsh (1995, p. 164) identified other solution, namely to give a strong commitment to the central bank for keeping inflation under control, "by making the central banker's employment contingent on achieving prespecified inflation targets". In both cases, a higher independent central bank could implement the monetary policy necessary to get lower inflation (Crowe \& Meade, 2007, p. 70).

Consequently, there are two special risks which threat the central bank independence (Fraser, 1994, p. 2):

- the policy makers' and politicians' tendency to boost the economy further than its potential; 
- the governments' temptation to accumulate budgetary deficits and cover them through financial resources borrowed from central bank.

In order to face these risks, central banks should have a higher independence, because monetary authorities are more distressed regarding the stability of in comparison with politicians.

\subsection{The Critics to Central Bank Independence}

Although there are arguments that support the importance of central bank independence, there are two serious arguments against this issue (Eijffinger \& de Haan, 1996, p. 16). First argument insists on the fact that an independent central bank is not democratic accountable to the public, being invocated mostly by the Anglo-Saxon countries. Several researchers view monetary policy as comparable to other tools of macroeconomic policy. Consequently, it should be completely decided by the representatives that are elected in a democratically way. So, this approach implies a direct participation of political authorities in conducting of central bank's policy. Nevertheless central bank independence and democratic accountability could be carried out in diverse manners, through separating the tasks between executive authority and monetary authority.

The second argument against central bank independence is concerned about the potential damages caused to macroeconomic policy coordination (Eijffinger \& de Haan, 1996, p. 18). A number of theoretical researchers have given attention to the conflict that may occur when the government is responsible of fiscal policy and the central bank is responsible of monetary policy. The both authorities focus on their own priorities regarding their goals and may decide to work together or not in putting into practice of their policies. If the government and central bank choose to not cooperate, a conflict of interests between their policies is expected to appear. Nevertheless this literature concentrated on lack of policies coordination has some shortcomings. Trying to surpass the limitations of such researches, Debelle (1993, cited by Eijffinger \& de Haan, 1996, p. 20) concluded that the objectives of fiscal policy have an impact on both the central bank independence and the rate of inflation. In its opinion central bank independence could decrease inflation, but it could lead to a lower social welfare, as well, and the optimal level of the central bank conservatism relies on public's dislike to inflation and output fluctuation.

\subsection{Definition of Central Bank Independence}

Central bank independence in relation with the executive authority (government) was placed into the centre of many studies during the recent decades and, thus, there are various meaning of this concept. Some of them are presented below.

Friedman (1962, cited by Eijffinger \& de Haan, 1996, p. 1) was speaking about central bank autonomy, arguing that this can be seen as a relation between central bank and executive authority that is similar to the relation between judiciary and executive authority. The judiciary should act only according to the law given by the legislature, and it may be forced to act in a different way only on the basis of a change into law.

According to Hasee (1990, cited by Eijffinger \& de Haan, 1996, p. 2) there exist three dimension of central bank independence: personnel independence, financial independence and policy independence. Personnel independence demotes the government's intervention in appointment procedures of members of central bank's governing body. Financial independence denotes the capacity of government to finance its expenditure either directly or indirectly by borrowing from central bank. Policy independence denotes the manoeuvring room granted to the central bank in setting and implementing of monetary policy. 
Grilli, Masciandaro \& Tabellini (1991, p. 366) have indentified two approaches of central bank independence, speaking about political and economic independence. Central banks political independence represents "the capacity to choose the final goal of monetary policy, such as inflation or the level of economic activity". Central bank's economic independence represents "the capacity to choose the instruments with which to pursue these goals".

Debelle \& Fisher (1994, p. 197) have discussed about two types of independence, namely goal independence and instrument independence. "A central bank has goal independence when it is free to set the final goals of monetary policy" without the interference of the government. Therefore, a central bank that enjoys independence in setting its goal may choose, such as, that "price stability was less important than output stability and act accordingly". In fact, this type of independence is associated with Grilli, Masciandaro \& Tabellini (1991) approach of political independence. Debelle \& Fisher (1994, p. 197) consider that " $a$ bank that has instrument independence is free to choose the means by which it seeks to achieve its goals". If the central bank's objectives are accurately set in an agreement with the executive authority, it doesn't have goal independence. But the central bank can enjoys instrument independence if it chooses the ways through which it aims to accomplish the pre-allocated goals (Debelle \& Fisher, 1994, p. 197).

Fraser (1994, p. 3) believes that the central bank independence signifies "to give central banks a charter which includes a strong commitment to price stability, and the freedom to pursue it".

A very brief definition of central bank independence, that synthesise the previous definitions, was given by de Haan \& Eijffinger S. (2017, p. 1), who consider that the "central bank means that monetary policy is delegated to unelected officials and that the government's influence on monetary policy is restricted".

\subsection{Measuring Central Bank Independence}

Though to measure the central bank independence is a delicate matter, during the time different indices were developed, most of them focusing on legal independence. The most largely used legal indicators of central bank independence were constructed by Alesina (1988), Grilli, Masciandaro \& Tabellini (1991), Cukierman, Webb \& Neyapti (1992), Eijffinger \& Scharling (1992). Although all indices are founded on comparable criteria that describe legal independence, they sometimes provide very different results.

First attempt to measure the legal independence belongs to Bade \& Parkin (1988, p. 3-4), who made a revolutionary research grouping a number of central banks in four categories depending on the degree of legal independence. Taking in consideration 3 matters -1 ) the connections between the central bank and the executive in making of monetary policy; 2) the role of government in appointment procedures of members of central bank's policy-making organs; 3) the grade of financial control exercise by the executive over central bank - the authors granted a score of 1 to the least independent central banks and a score of 4 to the most independent central banks.

On the basis on the unpublished paper of Bade \& Parkin (1988), Alesina (1988, p. 40) constructed an index of central bank legal independence, considering that the level of independence relies on at least four factors: 1) the institutional and official relation between central bank and government; more exactly, who appoints governing body members of central bank, whether executive's official are presented in central bank's board and if specific policies require government' agreement; 2) the informal relations and contacts between central bank's members and government's officials; 3 ) relations between the central bank and the government regarding budgetary and financial matters; 
and 4) macroeconomic relations between the central bank and the executive; for instance if there exist some rules that put pressure on central bank to accommodate fiscal policy. Similar to previous authors, Alesina ranks the central bank from 1 to 4.

Grilli, Masciandaro \& Tabellini (1991) conceived an index of legal independence that is the sum of their indicators for assessment of political independence and economic independence, and ranges from 3 to 13. There are three features of monetary regime that influence political independence, namely 1) the "procedure for appointing" the monetary authority governing bodies' members; 2) the relation between "these bodies and the government" and 3) the central bank's "formal responsibilities" (Grilli, Masciandaro \& Tabellini, 1991, p. 366). The economic dimension of independence was assessed by taking in consideration 1) the government' intervention in deciding "how much to borrow from the central bank" and 2) the "nature of monetary instruments" controlled by the monetary authority (Grilli, Masciandaro \& Tabellini, 1991, p. 368).

Eijffinger \& Scharling (1992, p.13) developed an index of central bank autonomy on the basis of three criteria: 1) who has the final responsibility for monetary policy (solely central bank; central bank and the government; or government; 2) the nonexistence or existence of a government official in the governing body of the central bank, and 3 ) the percentage of board appointees given by executive. If the law states that the central bank has single responsibility for monetary policy, that country obtains a double score. Their index ranges from 1 to 5 .

Cukierman, Webb \& Neyapti (1992, p. 356-359) composed an index that measures legal independence, by coding sixteen different legal features of central bank stipulated in their chaerrter, which are assembled in four groups of matters: 1) appointment and dismissal of the central bank's governor and its term of office;
2) resolution of conflicts that arise between the government and the central bank regarding monetary policy and the involvement of the monetary authority in budgetary procedure; 3) the relative importance of price stability in comparison with other monetary authority's objectives stipulated in the chart; 4) fixing some restrictions on the ability of monetary authority to lend funds to public institutions. By aggregating these criteria, their index ranges between 0 and 1 .

\section{Central Bank Independence and}

\section{Inflation}

Numerous studies have focuses on the relation between central bank independence and inflation, but empirical results are not concluded. On the one hand, some studies demonstrated that there is a negative relationship between central bank independence and rate of inflation, other could not prove the existence of such correlation.

Constructing different central bank independence indices, early cross-country researches (Alesina, 1988; Grilli, Masciandaro \& Tabellini, 1991; Cukierman, Webb \& Neyapti, 1992, Alessina \& Summers, 1993; Eijffinger, Schaling \& Hoeberichts, 1998) have found that a higher independence of central bank is significantly linked with a smaller rate of inflation in developed economies. But the negative correlation was not validated for developing countries. Moreover, the improvement in evolution of inflation obtained by increasing independence of central bank was accomplished without reducing economic growth (Grilli, Masciandaro \& Tabellini, 1991, p. 376).

In the meantime, several transition economies and emerging countries adopted reforms that gave their central banks higher level of independence. Thus, many following studies have also included in analysed samples the transition and developing countries. Using the same 
codification employed by Cukierman, Webb \& Neyapti (1992) for measuring legal independence, Cukierman, Miller \& Neyapti (2002, p. 237) have investigated the legal independence of the new monetary authorities in 26 former socialist economies. Their main finding was that the legal independence and the rate of inflation are significantly and negative correlated also in the transition countries, "but for sufficiently high and sustained levels of liberalization, and controlling for other variables".

Jacome \& Vasquez (2005, p. 24) analysed the relation between inflation and legal independence of central bank in 24 Latin American and Caribbean countries. Computing three different indexes of legal independence, and "after controlling for international inflation, the exchange regime, and the occurrence of banking crises", they provide empirical support for a significant inverse relationship between legal independence of central bank and inflation rate.

By contrast, several studies have not found a negative relation between central bank independence and inflation. For example, investigating the effects of institutional reforms in 23 OECD countries, Daunfeldt \& de Luna (2008) demonstrated that the stability of prices was reached before the central bank enjoyed a higher level of independence. They concluded that central bank independence cannot be responsible for achieving a low level of inflation.

Employing data for the end of the year 2003 provided by database of IMF regarding central banks law, Crowe \& Meade $(2007$, pp. 71, 74) recalculated the legal independence index introduced by Cukierman, Webb \& Neyapti (1992), by included in the sample 27 additional countries (12 developing countries and 15 transition economies in central Europe and ex-Soviet Union). Their investigation showed that the apparent inverse relationship between central bank independence and inflation does not exist at the level of the entire sample. But when they separated the countries into two groups - industrial countries and, respectively, developing countries - the inverse relationship was evident only for the group of transition countries in central Europe.

Hayo \& Hefeker (2002, p. 669) reviewed the theoretical arguments and empirical support for central bank independence as a necessary and/or sufficient instrument for attaining price stability. Their finding was that central bank independence "is not a sufficient condition" for attaining the stability of price, being just "an instrument among many" for achieving low inflation. Moreover, the independence of central bank "is not a necessary condition" for attaining this goal, while "it may be the appropriate solution" for several economies.

Daunfeldt, Landstrom \& Rudholm (2014, p. 4) have extended the study of Daunfeldt and de Luna (2008), taking in consideration 131 countries where central bank reforms have possible been engaged. They found that central bank independence have contributed to achieving a lower inflation "but only when countries with historically high inflation rate are included" in the sample. However, countries experiencing smaller rate of inflation have decrease it with no institutional reforms conferring higher independence to central banks.

\section{Central Bank Independence and Inflation in EU-28}

In this article, we intend to analyze the relation between inflation and the central bank independence. The analyzed sample includes the 28 member countries of the European Union. The analyzed period is 2008-2012. The data source for inflation is Eurostat, and data from Garriga (2016) study was used for the independence of central bank. The central bank independence was 
calculated by Garriga (2016) using the methodology proposed by Cukierman, Webb \& Neyapty (1992).

The methodology used to show the impact of the independence of central bank on inflation is the regression of panel data. The number of included observations is 140 . The econometric model used is as follows:

$$
\mathrm{INF}=\alpha+\beta * \mathrm{CBI}+\varepsilon_{\mathrm{i}}
$$

Where: INF - rate of inflation;

$\mathrm{CBI}$ - central bank independence;

$\varepsilon_{\mathrm{i}}$ - the residual variable;

$\alpha$ and $\beta$ - the coefficients whose values we want to estimate.
Analyzing the inflation rate histogram (graph no. 1), it is observed that the asymmetric coefficient is 2.39 , lower than the value of a normal distribution, indicating the presence of a right asymmetry, ie the righthand tail is longer. The kurtosis coefficient has a value of 14.07 greater than 3 (in the case of normal distribution), which is a larger vaulting than normal distribution, ie leptokurtic. The Jarque-Bera test, which allows us to analyze the distribution of the residue, leads us to reject the null hypothesis, the test results show that the residue does not follow a normal distribution.

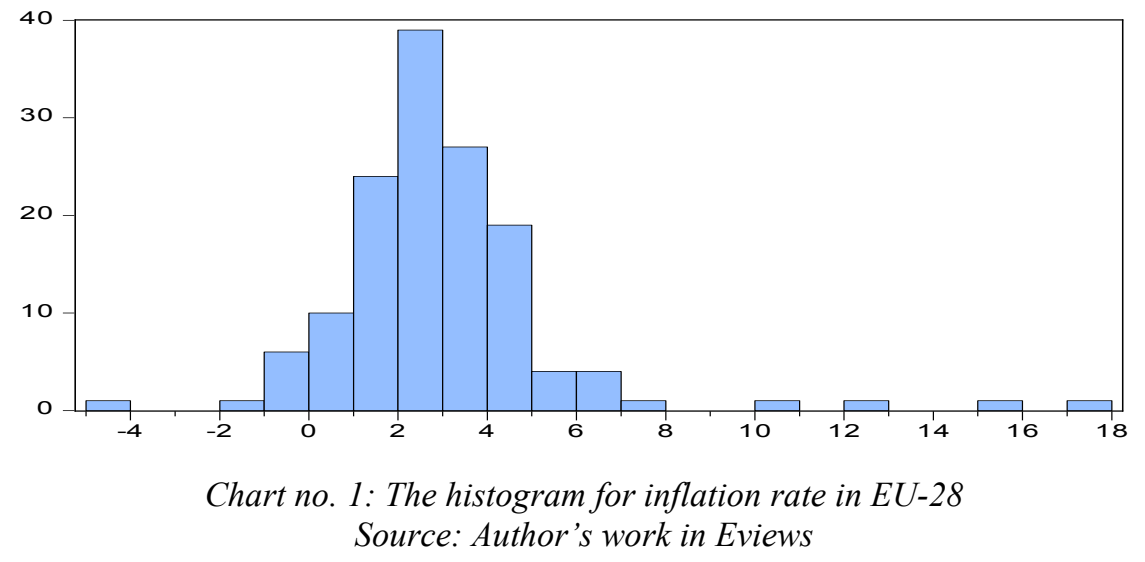

Regarding the series of independence of central bank, it is clear from the histogram (graph 2) that the asymmetric coefficient has a negative value, lower than the threshold of a normal distribution, which means that the analyzed distribution has a negative asymmetry, ie it is lengthened to the left. At the same time, the kurtosis coefficient has a value of 9.09 , which indicates a higher distribution than the normal one, thus being

leptokurtic. Analyzing the way the series is distributed with the values of the level of independence in terms of symmetry and the coefficient of kurtosis, we can say that the values do not pursue a normal distribution law. Interpreting the results of the JarqueBera test shows that the residue does not pursue a normal distribution; the probability coefficient resulting from the test is insignificant.

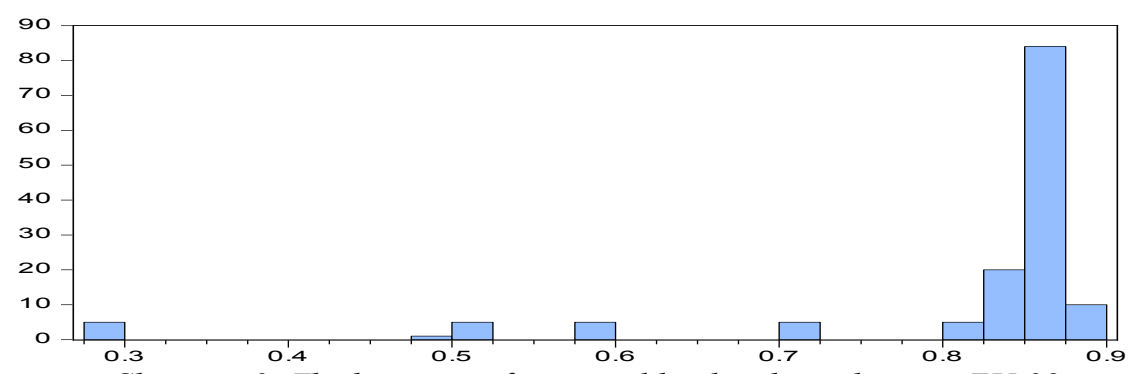

Chart no. 2: The histogram for central bank independence in EU-28 Source: Author's work in Eviews 
The results of the regression equation on panel data are presented in the following table:

Table no. 1

Empirical results

\begin{tabular}{|l|c|c|c|c|}
\hline & $(1)$ & $(2)$ & $(3)$ & $(4)$ \\
\hline $\mathrm{c}$ & $1.511368^{* *}$ & $0.389345^{* * *}$ & $3.212892^{* *}$ & $7.229574^{* *}$ \\
& $(1.130995)$ & $(0.247804)$ & $(1.13003)$ & $(2.101112)$ \\
\hline $\mathrm{ICB}$ & $1.8375^{* *}$ & $4.076998^{* *}$ & $-0.17931^{* * *}$ & $-5.49352^{* *}$ \\
& $(1.120322)$ & $(1.068772)$ & $(-0.05283)$ & $(-1.27001)$ \\
\hline $\mathrm{R}^{2}$ & 0.1909 & 0.1249 & 0.22 & 0.3496 \\
\hline
\end{tabular}

Source: Own work in Eviews

Note: $* *$ and $* * *$ represent the rejection of the null hypothesis for $5 \%$ and $10 \%$, respectively.

In parentheses are $\mathrm{t}-$ Student values.

According to the initial regression, which included the 28 countries, it is noted that with an increase in the central bank independence by one percentage point, inflation increases by $1.8375 \%$, so we can say that there is a positive correlation between the two variables. Dumiter \& Şoim (2010) also had a positive relationship in their study conducted on a sample made of 40 countries (20 emerging economies and 20 developed economies) in the period 2005-2009. Using the test Student, it can be noticed that the level of independence is an explanatory variable less relevant to inflation rate (the probability of impact being $24 \%$ ). The outcome may be influenced by the fact that the analyzed period is post-crisis, being the period when monetary policy decisions and legislative regulations adopted to mitigate the financial crisis were not traditional, sometimes resorting to unconventional measures. The determination report shows that the central bank independence in EU Member States is not the only explanatory factor for the inflation rate, since its value is only $19 \%$.

Current studies suggest that there is a negative correlation between inflation rate and independence of central bank in the recent years (in which the central banks in advanced economies have not fought with high inflation, but rather with a low inflation for a long time). According to these studies, a constant negative relation between inflation rate and independence of central bank over time and in economies stayed intact if we consider a narrower measure of independence that perceives the autonomy of the central bank in the choosing and using of monetary policy instruments. Instead, the importance of broader independence measures was reduced in a time when central banks had to take on other tasks. So, we divided the initial sample into three sub- samples. Thus the second regression includes countries (Sweden and Denmark) where central bank independence is less than 0.51 . The obtained results show also a positive relationship between the variables analyzed. In the third regression, the negative relation between inflation rate and independence of central bank can be observed. This sub-sample includes countries (EU 26) with a central bank independence more than 0.51 . The obtained results are in line with those obtained in the literature. The negative relationship is also found in the last regression.

\section{Conclusion}

Central bank independence has been placed in the centre of many studies during recent decades. Several researchers have argued that a high level of central bank independence is related to a small inflation. This is the reason for way an increasing number of developing countries have applied institutional reforms that confer a more independence to their central bank. But some recent studies have put under the 
question the existence of the negative relation between independence of central bank and rate of inflation, but they could not come with arguments against the central bank independence.

Investigating the evolution of inflation in EU-28 in connection with the state of central bank independence, we discover that for countries with a central bank independence of more than 0.51 , the relationship between the two variables is negative. But for countries with values lower than 0.51 , the relationship is positive. It seems that precisely these values of
Sweden and Denmark influence the positive relationship achieved in the first regression.

Nowadays, some researchers consider that the financial crises put de central bank independence under threat, but a recent study showed that more than $90 \%$ among central bank governors (of 55 questionnaires received from central banks' governors) and more than $89 \%$ among academics (of 156 questionnaires received from academic economists) felt that central bank independence has change little or not at all (Blinder, Ehrmann, de Haan \& Jansen, 2017, pp. 3, 38).

\section{REFERENCES}

Alesina, A. (1988). Macroeconomics and Politics, NBER Macroeconomics Annual, Volume 3, 13-62.

Alesina, A., \& Summers, L. (1993). Central Bank Independence and Macroeconomic Performance: Some Comparative Evidence, Journal of Money, Credit and Banking, 25 (2), 151-162.

Bade, R., \& Parkin, M. (1988). Central Bank Laws and Monetary Policy, London, Ontario: University of Western Ontario.

Barro, R. J., \& Gordon, D. B. (1983). Rules, discretion and reputation in a model of monetary policy, Journal of Monetary Economics, 12, 101-121.

Binder, A., Ehrmann, M., de Haan, J., \& Jansen, D. J. (2017). Necessity as the mother of invention: monetary policy under crisis, Working Paper Series, No. 2047, ECB

Crowe, C. \& Meade, E. E. (2007). The Evolution of Central Bank Governance around the World, Journal of Economic Perspectives, 21, (4), 69-90.

Cuckierman, A., Webb, S., \& Neyapti, B. (1992). Measuring the independence of central bank and its effect on policy outcomes, Word Bank Economic Review, no. 6.

Cukierman, A., Miller, G., \& Neyapti, B. (2002) Central bank reform, liberalization and inflation in transition economies - an international perspective, Journal of Monetary Economics, No. 49, 237-264.

De Haan, J., \& Eijffinger, S. (2017). Central bank independence under threat?, CEPRP Policy Insight, No. 87.

Debelle, G., \& Fisher, S. (1994). How Independent Should a Central Bank Be?, Goals, Guidelines and Constraints Facing Monetary Policymakers, Federal Reserve Bank of Boston, Proceedings of a Conference Held at North Falmouth, Massachusetts, Conference Series No. 30, 195-222.

Daunfeldt, S., \& de Luna, X. (2008). Central bank independence and price stability: evidence from OECD-countries, Oxford Economic Papers 60(3), 410-422.

Daunfeldt, S., Landstrom, M., \& Rudholm, N. (2014). Are Central Bank Independence Reforms Necessary for Achieving Low and Stable Inflation?, available at: http://www.usbe.umu.se/digitalAssets/137/137225 cbi_inflation_140128.pdf, accessed September 30, 2017. 
Dumiter, F. C., \& Șoim, H. F. (2010). The correlation between central bank independence and inflation in developed and emerging countries, Proceedings of the 5th WSEAS International Conference on Economy and Management Transformation, issue I, 180-185.

Eijffinger, S., \& de Haan, J. (1996). The political economy of Central Bank Independence, Special Papers, International Economics, No. 19.

Eijffinger, S., \& Schaling E. (1992). Central bank independence: Searching for the philosophers's stone (Revised version), CentER Discussion Paper, Vol. 51

Eijffinger, S., Schaling E., \& Hoeberichts M. (1998). Central bank independence: A sensitive snalysis, European Journal of Political Economy, Vol. 14, 73-88

Fraser, B. W. (1994). Central bank independence: what does it mean?, Reserve Bank of Australia Bulletin.

Garriga, A. C. (2016). Central Bank Independence in the Word: A New Dataset, International Interactions 42 (5), 849-868.

Grilli, V., Masciandaro, D., \& Tabellini, G. (1991). Political and Monetary Institutions and Public Financial Policies in the Industrial Countries, Economic Policy, 6 (13), 341-392.

Hayo, B., \& Hefeker, C. (2002). Reconsidering Central Bank Independence, European Journal of Political Economy, Vol. 18, 653-674.

Jacome, L., \& Vaszquez, F. (2005). Any link between legal central bank independence and inflation? Evidence from Latin America and the Caribbean, IMF Working Paper, $W P / 05 / 75$.

Kydland, F. E., \& Prescott, E. C. (1977). Rules Rather than Discretion: the Inconsistency of Optimal Plans, The Journal of Political Economy, 85 (3), 473-492.

Richard, D. (2003). Time-inconsistent monetary policies: recent research, FRBSF Economic Letter, No. 10.

Rogoff, K. (1985). The Optimal Degree of Commitment to an Intermediate Monetary target, Quarterly Journal of Economics, 1169-1189.

Walsh, C. E. (1995). Optimal Contracts for Central Bankers, The American Economic Review, 85 (1), 150-167. 